\title{
Search, inspection and selection of new source material for millet breeding
}

\author{
Larisa Sokurova, and Aishat Yandieva \\ ${ }^{1}$ Institute of agriculture - the branch of the RAS (Russian Academy of Sciences) Kabardino-Balkarian \\ Research Center, Kirov str., 224, 360004 Nalchik
}

\begin{abstract}
Comprehensive inspection of millet original forms and their involvement in the breeding process to create new varieties and lines is an urgent problem and is of great theoretical and practical importance $[3,4]$. New varieties should be resistant to abiotic stresses and ecological plasticity, as global climate changes do not allow new varieties and cross-breeds to realize their potential possibilities, most of them are realized only by 20 $40 \%$. In this regard, it is important to take into account the specifics of global and local climate change, as well as the sharply increased frequency of extreme weather events over recent decades. [5] In general, in the genetic variability of cultivated plants, the most deficient category is resistance to the action of biotic and abiotic stressors.
\end{abstract}

\section{Introduction}

The success of crop breeding in Russia is facilitated by the plant genetic resources of VIR, which are among the four largest in the world, where there are more than 9 thousand samples of millet [1].

At the Institute of Agriculture of the Kabardino Balkarian Research Center of the Russian Academy of Sciences, there is a VIR control point. Annually, about 100-150 varieties of the millet unique world collection are kept alive, reproduced and inspected. The ones that distinguished from them on the basis of economically valuable traits are used in the further breeding of the institute.

The inspection of variability degree of genotypes in response to varying external conditions makes it possible to create widely adaptive varieties and cross-breeds, which, under favorable conditions, give the greatest and most stable yield [2].

The Institute of Agriculture of the Kabardino Balkarian Research Center is working on expanding, preserving and inspecting the characteristic collections of millet, isolating and creating new sources and donors of valuable traits for use in adaptive breeding. The ongoing investigations on millet are aimed at expanding the genetic diversity of the initial material, inspecting and improving the architectonics of plants and physiological adaptation mechanisms, and contributing to an increase in the adaptive potential of the created varieties $[6,7]$.

Based on the inspection and assessment of samples from the collection of millet seeding VIR, promising initial material (donors and genetic sources) was identified, which will be involved in the breeding process to create new stress-resistant genotypes [8]. 
The most centralized, economically and environmentally effective means of increasing the size and quality of the crop are new varieties and cross-breeds due to resource-energy efficiency, environmental sustainability, environmental protection and profitability of agricultural production.

\section{Materials and methods}

The investigations were carried out in 2017-2019 on the experimental field of the Institute of Agriculture, located in the steppe zone of the KBR, which is characterized by insufficient moisture. The average annual precipitation according to multi-year data is $444 \mathrm{~mm}$. This zone is characterized by a pronounced continentality. Winters with little snow, moderately cold, unstable, with frequent thaws.

A stable transition of air temperature over $+10^{\circ} \mathrm{C}$ is observed in the spring on April 1520 , in the autumn on November 5 - 10.

Soils in the steppe zone are represented by ordinary black soil (chernozem). The thickness of the humus layer reaches $70-90 \mathrm{~cm}$, and the humus content in the plowing horizon ranges from 3 to $4.9 \%$. The content of mobile phosphorus in the soil ranges from 15.6 to $28.7 \mathrm{mg} / \mathrm{kg}$; exchangeable potassium 200-300 mg/kg (according to Machigin). The soil reaction is slightly alkaline.

The dynamics of plant growth was measured, the onset of phenophases, stages of organogenesis was marked and at the end of the growing season the yield was recorded. Resistance to lodging was determined visually according to a nine-point system in the phase of economic ripeness.

For laboratory analysis by quantitative traits before harvesting a bundle material in the amount of 25 plants of each sample was taken and analyzed for economically valuable traits, paying particular attention to plant height, length and type of panicle, its density, grain content, grain size, etc.

The inspection work on collection samples of millet was carried out in accordance with the VIR methodological instructions.

Over the years of investigation, we have inspected many different domestic and foreign samples of millet from the VIR world collection. They were sown annually on winter wheat using the RS-1 manual seeder at the optimum time for the zone. The seeding rate is 450 grains per $1 \mathrm{~m}^{2}$, the sowing method is ordinary.

\section{Results and discussion}

Assessing the weather conditions of the growing season of plants, it should be noted that May - June 2017 was favorable for the growth and development of millet. July and August were drier, precipitation was $34.3-23.6 \mathrm{~mm}$ with an average daily air temperature of $26.8-26.0^{\circ} \mathrm{C}$.

Table 1. Mean 10-day precipitation data and air temperature in the investigation years.

\begin{tabular}{|c|c|c|c|c|c|c|c|c|c|c|c|}
\hline \multirow[b]{2}{*}{$\begin{array}{l}\mathfrak{D}_{0}^{n} \\
\stackrel{0}{\Sigma}\end{array}$} & \multirow{2}{*}{$\begin{array}{l}\text { Ten- } \\
\text { day } \\
\text { peri } \\
\text { ods }\end{array}$} & \multicolumn{5}{|c|}{ Amount of precipitations, $\mathrm{mm}$} & \multicolumn{5}{|c|}{ Air temperature, ${ }^{\circ} \mathrm{C}$} \\
\hline & & 2017 & 2018 & 2019 & $\begin{array}{l}\text { Aver } \\
\text { age } \\
\text { in } \\
\text { three } \\
\text { year } \\
\text { s }\end{array}$ & $\begin{array}{l}\text { Aver } \\
\text { age } \\
\text { multi } \\
\text { sum } \\
\text { mer }\end{array}$ & 2017 & 2018 & 2019 & $\begin{array}{c}\text { Average } \\
\text { in three } \\
\text { years }\end{array}$ & $\begin{array}{c}\text { Average } \\
\text { multi } \\
\text { summer }\end{array}$ \\
\hline \multirow[t]{3}{*}{ May } & 1 & 11.2 & 11.2 & 39.1 & 20.5 & & 18.0 & 18.0 & 21.0 & 19.0 & \\
\hline & 2 & 34.4 & 16.9 & 17.2 & 22.8 & & 16.3 & 19.0 & 23.5 & 19.6 & \\
\hline & 3 & 33.9 & 59.0 & 16.0 & 36.3 & & 16.6 & 20.2 & 27.0 & 21.2 & \\
\hline
\end{tabular}


Table 1. Continued.

\begin{tabular}{|c|c|c|c|c|c|c|c|c|c|c|c|}
\hline May & $\begin{array}{l}\text { Amo } \\
\text { unt } \\
\text { mon } \\
\text { thly }\end{array}$ & 79.5 & 87.1 & 72.3 & 79.6 & 65.3 & 16.9 & 19.0 & 23.8 & $\begin{array}{l}9.9 \\
\end{array}$ & 16.2 \\
\hline \multirow[t]{4}{*}{ June } & 1 & 30.4 & 14.1 & 1.2 & 15.2 & & 21.0 & 21.3 & 36.0 & 26.1 & \\
\hline & 2 & 30.8 & 26.9 & 7.7 & 21.8 & & 20.4 & 21.5 & 36.0 & 25.9 & \\
\hline & 3 & 8.4 & $\begin{array}{ll}1.8 \\
\end{array}$ & 20.0 & 10.0 & & 23.8 & 24.3 & 38.0 & 28.7 & \\
\hline & $\begin{array}{l}\text { Amo } \\
\text { unt } \\
\text { mon } \\
\text { thly }\end{array}$ & 69.6 & 42.8 & 18.9 & 47.0 & 84.2 & 21.7 & 22.3 & 36.6 & 26.9 & 20.6 \\
\hline \multirow[t]{4}{*}{ July } & 1 & 14.0 & 0.3 & 6.1 & 6.8 & & 26.3 & 24.7 & 37.0 & 29.3 & \\
\hline & 2 & 1.8 & 45.9 & 34.4 & 27.3 & & 27.4 & 26.6 & 33.0 & 29.0 & \\
\hline & 3 & 18.5 & 40.6 & 16.2 & 25.1 & & 26.7 & 26.9 & 39.5 & 31.0 & \\
\hline & $\begin{array}{l}\text { Amo } \\
\text { unt } \\
\text { mon } \\
\text { thly }\end{array}$ & 34.3 & 86.8 & 56.7 & $\begin{array}{l}59.2 \\
\end{array}$ & 59.4 & 26.8 & 26.0 & 36.5 & 29.7 & 23.0 \\
\hline \multirow{4}{*}{$\begin{array}{r}\text { Aug } \\
\text { ust }\end{array}$} & 1 & 0.7 & 42.1 & 32.2 & 25.0 & & 29.1 & 23.7 & 36.0 & 29.6 & \\
\hline & 2 & 11.7 & 1.5 & 3.3 & 5.5 & & 24.3 & 22.6 & 40.0 & 28.9 & \\
\hline & 3 & 11.2 & 0 & 4.2 & 5.1 & & 24.8 & 22.8 & 39.5 & 29.0 & \\
\hline & $\begin{array}{l}\text { Amo } \\
\text { unt } \\
\text { mon } \\
\text { thly }\end{array}$ & 23.6 & 43.6 & 39.8 & 35.6 & 44.5 & 26.0 & 23.0 & 38.5 & 29.1 & \\
\hline $\begin{array}{l}\text { Tota } \\
\text { 1: }\end{array}$ & & $\begin{array}{c}207 . \\
0\end{array}$ & $\begin{array}{c}260 . \\
3\end{array}$ & $\begin{array}{c}197 . \\
7\end{array}$ & $\begin{array}{c}221 . \\
4\end{array}$ & $\begin{array}{c}253 . \\
4\end{array}$ & 22.8 & 22.5 & 33.8 & 26.4 & 22.5 \\
\hline
\end{tabular}

In 2018, $267.5 \mathrm{~mm}$ of precipitation fell in May-August and they were distributed more evenly, while the air temperature averaged $22.6{ }^{\circ} \mathrm{C}$ for four months. During the months of May and June, 87.1-42.8 $\mathrm{mm}$ fell, with an average daily air temperature of $17.8-22.0^{\circ} \mathrm{C}$ (tab. $1)$.

A concept of the degree of stability and the variation value of this trait in individual samples can be formed on the basis of their inspection.

There are three phases of the plant's response to stress factors - irritation, damage and adaptation. The first phase is characterized by a rapid deviation of many parameters from the standard and subsequent return to it. In the phase of damage, there is a discoordination of different metabolic links. The discoordination degree is positively correlated with the level of stress effort and negatively with plant resistance. Due to the interaction of opposite metabolic processes, the ratio of metabolites is standardized at a certain level, which is the final stage of adaptation.

The influence of unfavorable environmental factors (soil drought and high air temperature) made it possible to distribute millet samples into highly resistant, above average resistant, medium resistant and low resistant ones.

The inspected samples were distributed as follows: the highest resistance to overheating in the initial stages of development was shown by $6.2 \%$ of the samples to the total amount of material (81-100\% of germinated seeds). The assessment for resistance to overheating was 8.8 grades (according to the nine-point system in accordance with the CMEA international classifier).

The second group - resistance above the average included 14.3\% (44 samples) - from 61 to $80 \%$ of germinated seeds. The assessment for resistance to overheating was 8.1 grades.

The third group - medium resistant occupies 52.2\% (160 samples) - 41-60\% of germinated seeds. The assessment for resistance to overheating was 7.5-8.0 grades. 
The fourth group occupies $27.3 \%$ (84 samples), 19-40\% of seeds germinated - weak resistance to overheating in the initial stages of development, the assessment was 5.3 grades (Fig. 1).

The high productivity of plants and ecological plasticity in all the years of investigation were consistently demonstrated by the samples shown in Table 2.

The height of millet plants varies with an increase in the agricultural culture and, especially in humid years, accordingly, other morphological characteristics also change.

The inspected samples of millet were distributed in height as follows: very undersized $-60 \mathrm{~cm}$ high, low $-61-80 \mathrm{~cm}$, medium-sized $-80-100$, high $-100-12 \mathrm{~cm}$, respectively (Fig. 2).

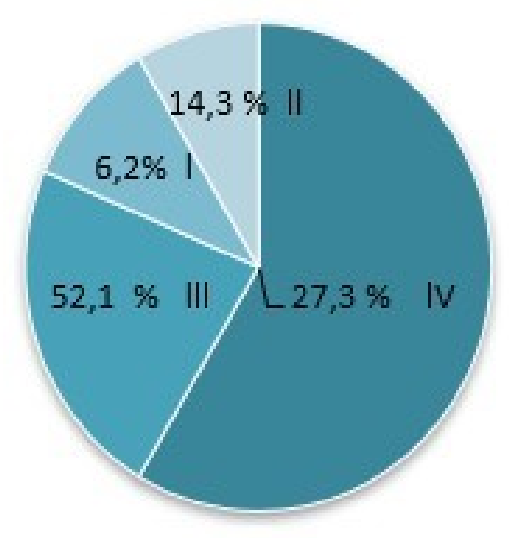

Fig. 1. Distribution of the inspected samples of seed millet by resistance groups (2017-2019).

Table 2. Donors and sources of millet isolated from the collection nursery-garden.

\begin{tabular}{|c|c|c|c|c|c|c|c|c|c|c|c|c|}
\hline \multirow[t]{2}{*}{ No. } & \multirow[t]{2}{*}{$\begin{array}{c}\text { VIR } \\
\text { catalog } \\
\text { number }\end{array}$} & \multirow{2}{*}{$\begin{array}{l}\mathrm{Yi} \\
\text { eld } \\
\text { (to } \\
\mathrm{n} / \mathrm{h} \\
\mathrm{a} \text { ) }\end{array}$} & \multirow{2}{*}{$\begin{array}{c}\text { Devi } \\
\text { ation } \\
\text { from } \\
\text { stand } \\
\text { ards, } \\
\text { ton } / \mathrm{h} \\
\text { a }\end{array}$} & \multirow{2}{*}{$\begin{array}{c}\text { Mas } \\
\mathrm{s} \text { of } \\
1,00 \\
0 \\
\text { grai } \\
\mathrm{ns}, \mathrm{g}\end{array}$} & \multirow{2}{*}{$\begin{array}{l}\text { Gra } \\
\text { in } \\
\text { wei } \\
\text { ght } \\
\text { fro } \\
\text { m } \\
\text { pan } \\
\text { icle } \\
\text { g }\end{array}$} & \multirow{2}{*}{$\begin{array}{l}\text { Num } \\
\text { ber } \\
\text { of } \\
\text { grain } \\
\text { s } \\
\text { from } \\
\text { panic } \\
\text { le, } \\
\text { pcs }\end{array}$} & \multirow{2}{*}{$\begin{array}{l}\text { Plant } \\
\text { heig } \\
\text { ht, } \\
\mathrm{cm}\end{array}$} & \multirow{2}{*}{$\begin{array}{c}\text { Pani } \\
\text { cle } \\
\text { lengt } \\
\mathrm{h}, \\
\mathrm{cm}\end{array}$} & \multirow{2}{*}{$\begin{array}{l}\text { Lo } \\
\text { dgi } \\
\text { ng, } \\
\text { gra } \\
\text { de }\end{array}$} & \multirow{2}{*}{$\begin{array}{c}\text { Falling } \\
\text { capacit } \\
\text { y, } \\
\text { grade }\end{array}$} & \multicolumn{2}{|c|}{$\begin{array}{l}\text { Resistance } \\
\text { to } \\
\text { abiofactors }\end{array}$} \\
\hline & & & & & & & & & & & $\begin{array}{c}\text { Abo } \\
\text { ve } \\
\text { avera } \\
\text { ge }\end{array}$ & $\begin{array}{c}\text { Highly } \\
\text { resista } \\
\text { nt }\end{array}$ \\
\hline 1 & $\begin{array}{l}\text { Caucas } \\
\text { ian } \\
\text { dawns }\end{array}$ & 1.3 & - & 8.8 & 2.2 & 250 & 88.8 & 19.6 & 9 & 9 & IV & \\
\hline 2 & $\begin{array}{l}\mathrm{K}- \\
6038 \\
\end{array}$ & 1.7 & 0.4 & 7.4 & 2.5 & 338 & 68.8 & 16.4 & 9 & 9 & IV & \\
\hline 3 & $\begin{array}{l}\mathrm{K}- \\
6061\end{array}$ & 1.8 & 0.5 & 8.0 & 2.7 & 337 & 74.8 & 18.0 & 9 & 9 & IV & \\
\hline 4 & $\begin{array}{l}\mathrm{K}- \\
6063 \\
\end{array}$ & 1.6 & 0.3 & 7.2 & 2.5 & 348 & 68.5 & 11.6 & 9 & 9 & IV & \\
\hline 5 & $\begin{array}{l}\mathrm{K}- \\
6070\end{array}$ & 1.7 & 0.4 & 7.7 & 2.7 & 350 & 74.6 & 19.6 & 9 & 9 & IV & \\
\hline 6 & $\begin{array}{l}\mathrm{K}- \\
6081 \\
\end{array}$ & 1.8 & 0.5 & 8.0 & 2.8 & 350 & 67.0 & 16.4 & 9 & 9 & IV & \\
\hline 7 & $\begin{array}{l}\mathrm{K}- \\
6130\end{array}$ & 2.4 & 1.1 & 8.2 & 3.5 & 427 & 88.4 & 20.6 & 9 & 9 & & $\mathrm{~V}$ \\
\hline 8 & $\begin{array}{l}\mathrm{K}- \\
6192\end{array}$ & 1.9 & 0.6 & 8.8 & 3.1 & 352 & 80.2 & 18.2 & 9 & 9 & & $\mathrm{~V}$ \\
\hline
\end{tabular}


Table 2. Continued.

\begin{tabular}{|c|c|c|c|c|c|c|c|c|c|c|c|c|}
\hline 9 & $\begin{array}{l}\mathrm{K}- \\
6195\end{array}$ & 1.8 & 0.5 & 7.8 & 2.7 & 346 & 67.4 & 16.0 & 9 & 9 & & V \\
\hline 10 & $\begin{array}{l}\mathrm{K}- \\
6202 \\
\end{array}$ & 1.9 & 0.6 & 7.5 & 2.9 & 386 & 78.8 & 21.0 & 9 & 9 & IV & \\
\hline 11 & $\begin{array}{l}\mathrm{K}- \\
6214 \\
\end{array}$ & 1.7 & 0.4 & 7.4 & 2.7 & 365 & 78.4 & 16.6 & 9 & 9 & IV & \\
\hline 12 & $\begin{array}{l}\mathrm{K}- \\
6225\end{array}$ & 1.8 & 0.5 & 8.0 & 2.7 & 337 & 80.0 & 12.6 & 9 & 9 & & V \\
\hline 13 & $\begin{array}{l}K- \\
6295 \\
\end{array}$ & 1.9 & 0.6 & 7.2 & 3.0 & 416 & 76.5 & 16.0 & 9 & 9 & & V \\
\hline 14 & $\begin{array}{l}\mathrm{K}- \\
6365 \\
\end{array}$ & 1.7 & 0.4 & 8.4 & 2.6 & 309 & 73.6 & 15.7 & 9 & 9 & IV & \\
\hline 15 & $\begin{array}{l}\mathrm{K}- \\
6367 \\
\end{array}$ & 2.1 & 0.8 & 7.5 & 3.2 & 426 & 85.6 & 21.0 & 9 & 9 & & V \\
\hline 16 & $\begin{array}{l}\mathrm{K}- \\
6368 \\
\end{array}$ & 2.3 & 1.0 & 7.9 & 3.4 & 430 & 82.0 & 22.6 & 9 & 9 & & V \\
\hline 17 & $\begin{array}{l}\mathrm{K}- \\
6417 \\
\end{array}$ & 1.7 & 0.4 & 7.2 & 2.7 & 375 & 73.5 & 16.0 & 9 & 9 & IV & \\
\hline 18 & $\begin{array}{l}\mathrm{K}- \\
10034 \\
\end{array}$ & 2.4 & 1.1 & 8.3 & 3.6 & 434 & 84.4 & 23.0 & 9 & 9 & & V \\
\hline 19 & $\begin{array}{l}\mathrm{K}- \\
10086\end{array}$ & 2.5 & 1.2 & 8.4 & 3.6 & 430 & 80.6 & 21.0 & 9 & 9 & & V \\
\hline 20 & $\begin{array}{l}\mathrm{K}- \\
6223 \\
\end{array}$ & 1.7 & 0.4 & 8.0 & 2.6 & 325 & 68.0 & 16.2 & 9 & 9 & IV & \\
\hline 21 & $\begin{array}{l}\mathrm{K}- \\
1522 \\
\end{array}$ & 2.8 & 1.5 & 8.2 & 3.0 & 366 & 84.4 & 27.2 & 9 & 9 & & V \\
\hline 22 & $\begin{array}{l}\mathrm{K}- \\
1876 \\
\end{array}$ & 2.7 & 1.4 & 8.0 & 3.8 & 475 & 83.4 & 26.1 & 9 & 9 & & V \\
\hline 23 & $\begin{array}{l}\mathrm{K}- \\
5451 \\
\end{array}$ & 2.8 & 1.5 & 8.3 & 3.7 & 455 & 99.6 & 30.0 & 9 & 9 & & V \\
\hline 24 & $\begin{array}{l}\mathrm{K}- \\
5464 \\
\end{array}$ & 3.0 & 1.7 & 8.0 & 2.9 & 362 & $\begin{array}{c}102 . \\
1\end{array}$ & 34.0 & 9 & 9 & & V \\
\hline 25 & $\begin{array}{l}\mathrm{K}- \\
5466 \\
\end{array}$ & 2.9 & 1.6 & 8.8 & 3.5 & 397 & 88.0 & 28.2 & 9 & 9 & & V \\
\hline \multirow[t]{2}{*}{26} & $\begin{array}{l}\mathrm{K}- \\
6054 \\
\end{array}$ & 2.9 & 1.6 & 7.8 & 4.4 & 500 & 84.2 & 28.8 & 9 & 9 & & V \\
\hline & $\mathrm{LCD}_{05}$ & 1.8 & & & & & & & & & & \\
\hline
\end{tabular}

In terms of plant height and panicle length, the distinguished genotypes are within the optimum zone, at which the highest yield is achieved.

One of the mechanisms of millet resistance to drought is the provision of water to plant bodies and tissues due to a well-developed water-conducting system of the stem and leaves. The more resistant samples to overheating and dehydration

turned out to be: K-6130, K-6-63, K-6070, K-6192, K-6214, K-6225, K-6295, K-6367, K-6368, K-10034, K-10086 withstood overheating and dehydration better than others.

Most of the grains were formed by plants of the sample K-6130, K-6295, K-6367, K6368, K-10034, K-10086.

The excess over the Caucasian dawns standard variety is $60-185$ pieces per plant. The index of the number of grains in a panicle is positively associated with the duration of the growing season and negatively with the grain size, but their various combinations are also possible. The selection of individual plants for this trait is difficult because of its great variability under the influence of environmental conditions.

Early ripeness was shown by 9 samples of the collection, which ripen 15-20 days earlier than the Caucasian dawns standard variety. Yield data for the investigation years are shown in Table 2. The yield data analysis shows that in the steppe zone of Kabardino Balkaria, the following samples were significantly distinguished by grain yield over the investigation 
years: K-6330, K-6367, K-6368, K-10034, K-10086, K-1522, K-1876, K-5451, K-5455, K5464, K-5466, K-6054, K- 6130, K-6063, K-6070, K-6192, K-6214, K-6225, K-6295, K$2131, \mathrm{~K}-2306, \mathrm{~K}-5455, \mathrm{~K}-5456, \mathrm{~K}-5457$. The excess over the standard variety is $0.5-1.7$ ton/ha.

By the weight of 1,000 grains the samples were characterized in the range of 7.2-9.2 $\mathrm{g}$. High weight of 1,000 grains was shown by K-1522, K-1876, K-2131, K-2306, K-5451, K5433, K-5456, K-5464, K-5466, K-6061, K-6081, K-6130, K-6225, K-6365, K-10034, K10086, K-6223 samples. The highest weight of 1,000 grains was shown by K-6192, K-5456, and K-5466 samples (table. 2).

\section{Conclusions}

The inspection of plant productivity relationship with structural elements in years contrasting with weather conditions enables the breeder to more effectively select the desired forms, taking into account the specific growing conditions.

The investigations carried out specify that it is promising to conduct selection according to grain size, panicle grain content, and an increase in their size.

\section{References}

1. N. P. Agofonov, World Millet Collection and Its Use in Practical Breeding, 69 (1970)

2. E. N. Zolotukhin, N. L. Tikhonov, L. N. Lizneva, et al., Actual problems of breeding and seed production of grain crops in the southeastern region, 46 (1999)

3. A. F. Kurtseva, Genetic resources of the millet collection and their use in the breeding process, 62 (1994)

4. N. I. Vavilov, Theoretical Foundations of Breeding (1987)

5. N. P. Agofonov, Improvement of Breeding and Seed Production and Millet Cultivation Technology, 9 (1985)

6. L.Kh. Sokurova, Sustainable Development: Concepts, 306 (2017)

7. L.Kh. Sokurova, Legumes and cereals, 3(67) (2018)

8. V. A. Ilyin, Yu. Ya. Mikhailova, O. S. Rasskazova, Ways of creating high-quality varieties of millet. Breeding and Seed Production of Millet, 61 (1973) 